\title{
c-Fos Facilitates the Acquisition and Extinction of Cocaine-Induced Persistent Changes
}

\author{
Jianhua Zhang, ${ }^{1}$ Lu Zhang, ${ }^{2}$ Hongyuan Jiao, ${ }^{2}$ Qi Zhang, ${ }^{2}$ Dongsheng Zhang, ${ }^{2}$ Danwen Lou, ${ }^{2}$ Jonathan L. Katz, ${ }^{3}$ and \\ Ming $\mathrm{Xu}^{2}$ \\ ${ }^{1}$ Division of Neuropathology, Department of Pathology, University of Alabama at Birmingham, Birmingham, Alabama 35294, ${ }^{2}$ Department of Anesthesia \\ and Critical Care, University of Chicago, Chicago, Illinois 60637, and ${ }^{3}$ Medications Discovery Research Branch, National Institute on Drug Abuse, \\ Baltimore, Maryland 21224
}

Development of drug addiction involves persistent neurobiological changes. The dopamine $\mathrm{D}_{1}$ receptor is involved in mediating cocaineinduced neuroadaptation, yet the underlying intracellular mechanisms remain unclear. We examined a potential role of the immediate early gene Fos, which is robustly and rapidly induced by cocaine via $\mathrm{D}_{1}$ receptors, in mediating cocaine-induced persistent neurobiological changes by creating and analyzing a mouse in which Fos is primarily disrupted in $\mathrm{D}_{1}$ receptor-expressing neurons in the brain. We show that the expression levels of several transcription factors, neurotransmitter receptors, and intracellular signaling molecules induced by repeated cocaine administration are altered in Fos-deficient brains. Dendritic remodeling of medium spiny neurons induced by repeated exposure to cocaine is blunted in the mutant mice. The mutant mice exhibit attenuated behavioral sensitization after repeated exposure to cocaine and more persistent memory of cocaine-induced conditioned place preference. Our findings indicate that c-Fos produced in $\mathrm{D}_{1}$ receptor-expressing neurons integrates mechanisms to facilitate both the acquisition and extinction of cocaine-induced persistent changes.

Key words: cocaine; dopamine $\mathrm{D}_{1}$ receptors; signal transduction; c-Fos; gene expression; dendritic morphology; behaviors

\section{Introduction}

Drug addiction is a complex brain disease (Wise, 2000; Dackis and O'Brien, 2005). A major feature of drug addiction is that, when acquired, it is long lasting and difficult to extinct (Koob et al., 1998; White and Kalivas, 1998; Hyman and Malenka, 2001; Nestler, 2001; Hyman et al., 2006). The dopamine (DA) pathways that originate in the midbrain ventral tegmental area (VTA) and project to the nucleus accumbens (NAc), amygdala (AMG), hippocampus (HIP), and prefrontal cortex (PFC) contribute to neurobiological mechanisms underlying the long-lasting actions of drugs of abuse (Koob, 1992). Abused drugs can increase synaptic levels of DA that are critical in reward and reinforcement (Koob et al., 1998; White and Kalivas, 1998; Hyman and Malenka, 2001; Nestler, 2001; Everitt and Wolf, 2002; Laakso et al., 2002; Kelley, 2004; Hyman et al., 2006).

$\mathrm{DA}_{1}$ receptors play a key role in mediating the neurobiological effects of cocaine. The $\mathrm{D}_{1}$ receptor is widely expressed in the brain, including the NAc, caudate-putamen (CPu), AMG, HIP, and PFC (Missale et al., 1998). Pharmacological studies have shown that the $\mathrm{D}_{1}$ receptor mediates cocaine-induced locomotor

Received March 8, 2005; revised Nov. 12, 2006; accepted Nov. 13, 2006.

J.Z. and M.X. are supported by National Institute on Drug Abuse Grants DA14644 and DA17323 and the Epilepsy Foundation of America. We thank D. French for helping with the locomotor activity measurement, Drs. E. Nestler and P. Ulery for kindly providing $\Delta$ FosB-positive brain tissues, and Dr. J. McGinty for advice on the anti-leumorphin antibody.

Correspondence should be addressed to Dr. Ming Xu, Department of Anesthesia and Critical Care, University of Chicago, Chicago, IL 60637. E-mail: mxu@dacc.uchicago.edu.

DOI:10.1523/JNEUROSCI.3795-06.2006

Copyright $\odot 2006$ Society for Neuroscience ～0270-6474/06/2613287-10\$15.00/0 responses, discriminative stimulus, reinforcing effects, and reinstatement (Cabib et al., 1991; Caine and Koob, 1994; Tella, 1994; Cervo and Samanin, 1995; Self et al., 1996; Baker et al., 1998; Tzschentke, 1998; Caine et al., 1999, 2000; Katz et al., 1999; Khroyan et al., 2000; Anderson et al., 2003). Chronic exposure to cocaine leads to persistent increases in $\mathrm{D}_{1}$ receptor-mediated inhibitory responses of NAc neurons (Henry and White, 1995; White and Kalivas, 1998) and reorganization of brain circuits involving $\mathrm{D}_{1}$ receptor-expressing neurons (Moratalla et al., 1996a). Using $D_{1}$ receptor mutant mice, we have shown that $D_{1}$ receptors mediate both behavioral and neurophysiological effects of cocaine (Xu et al., 1994a,b, 2000) (S. B. Caine, K. I. Gabriel, J. S. Berkowitz, L. H. Gold, G. F. Koob, S. Tonegawa, J. Zhang, and M. $\mathrm{Xu}$, unpublished observations).

The enduring nature of drug addiction suggests that persistent alterations occur in the brain after repeated exposure to abused drugs (Koob et al., 1998; White and Kalivas, 1998; Hyman and Malenka, 2001; Nestler, 2001; Hyman et al., 2006). Some of the alterations are mediated by transcription factors $\Delta$ FosB and the cAMP-response element binding protein (CREB) via regulating gene expression (Carlezon et al., 1998; Kelz et al., 1999; McClung and Nestler, 2003). The complexity of neuroadaptation and the multifaceted nature of behavioral changes induced by repeated exposure to cocaine, however, are likely influenced by additional transcription factors and their target genes (Greengard et al., 1999). The most prominent cellular responses to $D_{1}$ receptor agonists and cocaine administration are a transient upregulation of the immediate early gene (IEG) Fos in the NAc, CPu, AMG, 
and PFC (Graybiel et al., 1990; Nestler, 2001; McClung and Nestler, 2003; Kumar et al., 2005). A functional $D_{1}$ receptor is required for the c-Fos induction by cocaine (Drago et al., 1996; Moratalla et al., 1996b; Zhang et al., 2002a, 2004). The c-Fos proteins heterodimerizes with Jun family proteins resulting in activation protein-1 (AP-1) transcription complex formation and regulation of target gene expression (Morgan and Curran, 1991). c-Fos may coordinate neurobiological responses to cocaine by regulating gene expression in $\mathrm{D}_{1}$ receptor-expressing neurons (Zhang et al., 2005). To test this notion, we generated a mouse in which Fos is selectively deleted in this group of neurons. Our studies uncover a previously unknown role for c-Fos in which it functions in $\mathrm{D}_{1}$ receptor-expressing neurons to facilitate the acquisition and extinction of persistent changes induced by repeated cocaine administration.

\section{Methods and Methods}

Generation of Drd1-Cre and f/f-Fos-D - Cre mice. We cloned the mouse $\mathrm{D}_{1}$ receptor gene promoter and made a $\operatorname{Drd} 1$ (dopamine receptor $\mathrm{D}_{1}$ )Cre construct. Six independent lines of Drd1-Cre transgenic mice were generated by pronuclear injection (Dracheva et al., 1999). The homozygous floxed Fos mice, which contain loxP sites flanking the third and fourth exons of Fos that encode the DNA binding domain and the leucine zipper domain that are important for heterodimerization with the Jun family of proteins for transcriptional regulation, were made previously (Zhang et al., 2002b). We used Southern blotting to genotype mice with probes specific for the floxed Fos alleles and the Cre transgene (Zhang et al., 2002b). The genetic background of the mice used was 129X1/SvJ/ C57BL6J. We used $f / f-F o s-D_{1}-C r e$ and their various control littermates 7-28 weeks of age for all of the analyses. Similar to described previously (Zhang et al., 2002b), Drd1-Cre and homozygous floxed Fos mice exhibit identical Fos induction, behavioral, neuroanatomical, and gene expression patterns compared with wild-type mice. Equal number of male and female mice was used in the study.

Analysis of Cre activity using mice carrying a LacZ reporter gene. We bred the $\beta$-actin-loxP-stop-loxP-LacZ indicator mouse provided by Dr. David Anderson (California Institute of Technology, Pasadena, CA) (Tsien et al., 1996) with each of the six lines of Drd1-Cre transgenic mice. The resulting offspring carrying both the reporter gene and the Drd1-Cre transgene were identified by Southern blotting and were perfused at 3,7 , 18 , or 28 weeks of ages, and their brains were sectioned at $20 \mu \mathrm{m}$ thickness. The brain sections covering different regions were incubated overnight in a humidified chamber at $30^{\circ} \mathrm{C}$ with $1 \mathrm{mg} / \mathrm{ml} 5$-bromo-4-chloro3 -indolyl- $\beta$-D-galactopyranoside, $4 \mathrm{~mm} \mathrm{~K}_{4} \mathrm{Fe}(\mathrm{CN})_{6} \cdot 3 \mathrm{H}_{2} \mathrm{O}, 4 \mathrm{~mm}$ $\mathrm{K}_{3} \mathrm{Fe}(\mathrm{CN})_{6}$, and $2 \mathrm{mg} / \mathrm{ml} \mathrm{MgCl}_{2}$ in PBS. These sections were then counterstained with cresyl violet (Tsien et al., 1996). Neurons in five randomly selected $132 \times 132 \mu \mathrm{m}$ fields were counted for each brain region (Tsien et al., 1996). The percentage of reporter gene activation was calculated from the number of LacZ-positive blue neurons and the total number of neurons in each specific brain region (Tsien et al., 1996).

Immunohistochemistry. Mutant and wild-type mice were treated intraperitoneally with SKF81297 [(+/-)-6-chloro-7,8-dihydroxy-1phenyl2,3,4,5-tetrahydro- $1 H$-3-benzazepine] (5 mg/kg), cocaine (30 $\mathrm{mg} / \mathrm{kg}$ ), haloperidol (0.5 and $2 \mathrm{mg} / \mathrm{kg})$, kainic acid $(20 \mathrm{mg} / \mathrm{kg})$, or saline. Treated mice were perfused, brains were sectioned at $40 \mu \mathrm{m}$, and immunostaining using an antibody against c-Fos (Santa Cruz Biotechnology, Santa Cruz, CA) were performed (Zhang et al., 2004). For c-Fos and/or dynorphin immunostaining, we incubated sections with a rabbit antileumorphin antibody (Serotec, Oxford, UK) and a goat anti-c-Fos antibody (Santa Cruz Biotechnology) either alone or sequentially and developed them in Ni-diaminobenzidine (DAB) (dark color) and DAB (brown color), respectively (Zhang et al., 2004). We counted c-Fosand/or dynorphin-positive neurons (four brain sections per mouse for the NAc, and eight to nine sections per mouse for the $\mathrm{CPu}$ and other brain regions) using the MetaMorph computer program (Molecular Devices, Palo Alto, CA). This is followed by two-way ANOVA (Zhang et al., 2004).
Protein extract preparation and DNA-binding activity assay. We prepared nuclear extracts from the NAc and $\mathrm{CPu}$ and analyzed DNAbinding activities of the nuclear proteins using an electrophoretic mobility shift assay (Zhang et al., 2002b). Nuclear extracts were mixed with annealed AP-1 oligonucleotides 5 '-tcgacgtgactcagcgcgc- 3 ' that were end labeled, and the mixtures were electrophoresed in a nondenaturing gel. We scanned autoradiographs using a Molecular Dynamics scanner and analyzed the results by ImageQuant software (GE Healthcare, Little Chalfont, Buckinghamshire, UK). We performed super shifts as described previously (Zhang et al., 2002b). Polyclonal antibodies (Santa Cruz Biotechnology) against c-Fos, FosB, Fra-1 (Fos-related antigen 1), Fra-2, c-Jun, JunB, and JunD were used.

Cell transfection and protein extract preparation. U251 cells express endogenous Grin1 (glutamate receptor, ionotropic, NMDA 1) Gria2 (glutamate receptor, ionotropic, AMPA 1) and Cdk5 (cyclin-dependent kinase 5). NG cells express Grin1, Ctnnb [catenin (cadherin-associated protein), $\beta 1,88 \mathrm{kDa}$ ] and $C d k 5$. PC12 cells express Ctnnb, Cdk5r1, and Cdk5. We transfected these cells with 1-4 $\mu$ g of cytomegalovirus-Fos that contains a rat Fos cDNA by lipofection (Fugene6; Roche, Indianapolis, IN) (Zhang et al., 2002b). Forty-eight hours after the transfection, we harvested the cells and prepared protein extracts (Zhang et al., 2002b). All transfections were performed in duplicates, and each experiment was repeated at least three times.

Western blotting and data analyses. NAc and $\mathrm{CPu}$ extracts from individual mouse were prepared and Western blotting was performed (Zhang et al., 2002a,b). Extracts from the NAc and CPu of a $\Delta$ FosBexpressing mouse was used as a positive control for $\Delta$ FosB expression (Kelz et al., 1999; Zhang et al., 2002a). Results were visualized by enhanced chemiluminescence (GE Healthcare). Blocking peptides were used to verify the specificity of all antibodies. For the anti-c-Fos antibody, we also used a mutant mouse carrying a hippocampal Fos mutation and Fos-transfected cells to control for its specificity (Zhang et al., 2002b). We repeated each experiment at least three times. We quantified data by densitometer scanning and analyzed the gene expression results using two-way ANOVA.

Dendritic morphology and data analysis. One day after 28 consecutive days of injection of cocaine or saline, we perfused all mice and processed their brains for Golgi impregnation (Robinson and Kolb, 1999; Norrholm et al., 2003). The brains were cut into $200 \mu \mathrm{m}$ sections. Dendritic branches were counted from camera lucida drawings of at least 10 neurons from each hemisphere from either the NAc shell or $\mathrm{CPu}$ of each mouse. Dendritic spine density was analyzed from at least 30 dendrites from different neurons of the NAc shell or CPu from each mouse (Robinson and Kolb, 1999; Norrholm et al., 2003). Statistical analysis was performed using two-way ANOVA.

Behavioral analyses. For baseline motor activity and locomotor responses to $D_{1}$ and $D_{2}$ receptor agonist stimulation, mice were habituated for $1 \mathrm{~h}$ before all injections. Mice were then given an intraperitoneal injection of SKF81297 or quinpirole at two different doses or saline. Their locomotor responses were recorded for another hour after the injections. For behavioral sensitization measurement, mice were habituated for $1 \mathrm{~h}$ before all injections. All groups of mice were injected intraperitoneally in volumes of $1 \mathrm{ml} / 100 \mathrm{~g}$ once daily with saline for $2 \mathrm{~d}$ followed by two different doses of cocaine for $7 \mathrm{~d}$. On day 12, mice were challenged with 10 or $20 \mathrm{mg} / \mathrm{kg}$ cocaine. Mice were placed singly in clear acrylic chambers for the assessment of horizontal locomotor activity for $1 \mathrm{~h}$. The chambers were contained within monitors (Omnitech Electronics, Columbus, $\mathrm{OH}$ ) equipped with light-sensitive detectors, spaced 2.5 $\mathrm{cm}$ apart along two perpendicular walls. On the opposing walls and directed at the detectors were infrared light sources. One horizontal activity count was registered each time the subject interrupted a light beam. For rearing and grooming activities, different groups of mice were given an injection of either saline or $20 \mathrm{mg} / \mathrm{kg}$ cocaine, and behaviors were scored for $3 \mathrm{~s}$ intervals every $5 \mathrm{~min}$ for $60 \mathrm{~min}$ after the injection. Rearing is defined as rear feet on the chamber floor and both front feet simultaneously off the floor either against the wall or in the air. Grooming is defined as rapid repetitive movements of forelegs, hindlegs, or licking of body parts, directed at itself or a cage mate. At the cocaine doses used, we did not observe obvious stereotyped behaviors such as head bobbing, nail 


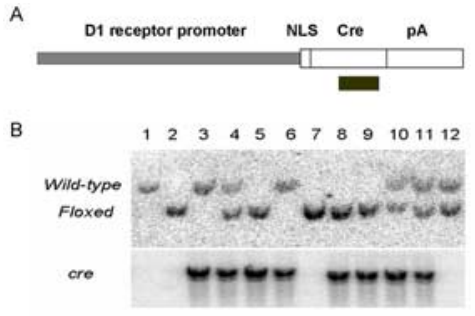

C

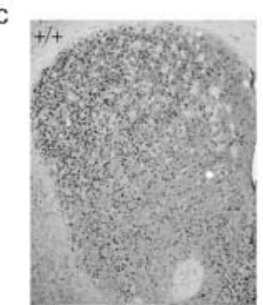

G

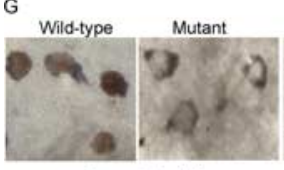

Dyn+c-Fos NAC
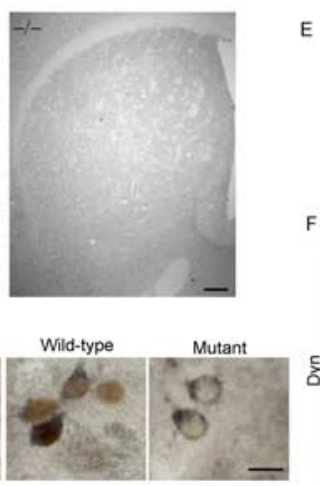

Dyn+c-Fos CPu

E

$\mathrm{F}$
D
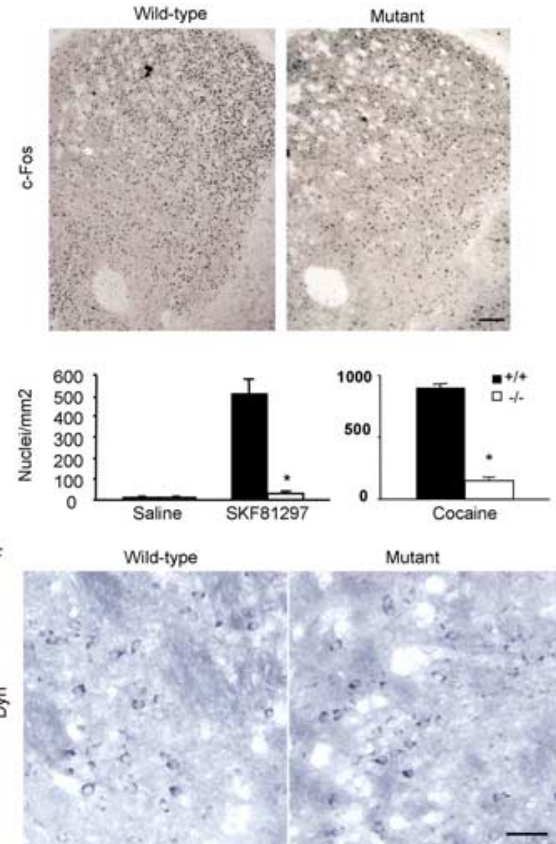

Figure 1. Generation of $f / f-F o s-D_{1}-C r e$ mice. $A$, The Drd1-Cre transgenic construct. It contains an 8 kb mouse $D_{1}$ receptor gene promoter, the $(r e$ gene, an intron, polyadenylation (pA), and protein nuclear localization sequence (NLS) for proper nuclear Cre expression. The location of a Cre probe is indicated. $\boldsymbol{B}$, Identification of the $f / f-F o s-D_{1}-C r e$ mice. Tail DNA were isolated from a family of mice produced by crossing the f/f--Fos mouse with the DC94 (120) Drd1-Cre transgenic mouse, digested by Bg/ll, and analyzed by genomic Southern blotting using a 3' probe for Fos (top) and Cre probe that detects an $8.5 \mathrm{~kb}$ band (bottom). Wild-type represents the normal Fos allele $(8.0 \mathrm{~kb})$, and Floxed indicates the floxed Fos allele $(5.2 \mathrm{~kb})$. C, c-Fos induction is significantly reduced in the CPu and NAc in $f / f-F o s-D_{1}-$ Cre mice $(-/-)$ compared with that in wild-type mice $(+/+; n=4$ each) $2 \mathrm{~h}$ after an acute $D_{1}$ receptor agonist SKF81297 injection $(5 \mathrm{mg} / \mathrm{kg})$. Data were obtained from five brain sections per mouse. Scale bar, $150 \mu \mathrm{m}$. D-G, c-Fos induction is significantly reduced in dynorphin-positive neurons in the CPu and NAc in f/f-Fos$D_{1}$-Cre mice (mutant; $n=6$ ) $2 \mathrm{~h}$ after an acute cocaine injection at the $30 \mathrm{mg} / \mathrm{kg}$ dose compared with that in wild-type mice ( $n=$ 17). Brain sections covering the (Pu and NAc regions were incubated with anti-c-Fos (D), anti-leumorphin (Dyn) $(\boldsymbol{F})$, or sequentially with anti-c-Fos and anti-leumorphin (Dyn) antibodies (G). Data were obtained from two to three brain sections per mouse. Scale bars: $\boldsymbol{D}, 150 ; \boldsymbol{F}, 30 ; \boldsymbol{G}, 10 \mu \mathrm{m}$. $\boldsymbol{E}$, Quantification of c-Fos induction by SKF81297 and cocaine. Two-way ANOVA was performed. ${ }^{*} p<0.01\left(F_{(1,30)}=3.25\right)$ compared with wild-type mice.

biting, taffy pulling, repetitive sniffing, and circling. Two-way repeatedmeasure ANOVA was used to analyze the effects of time, dose, and genotype on locomotor activities.

We used a five-phase conditioned place preference (CPP) procedure as described previously (Kreibich and Blendy, 2004) with modifications. During the preconditioning phase (days 1-2), mice were allowed to explore the CPP boxes that included two compartments with different colors and floor textures flanking a middle compartment (Med Associates, E. Fairfield, VT) for $20 \mathrm{~min}$, and time spent on each side was recorded. The next $8 \mathrm{~d}$ were the conditioning phase (days 3-10). Beginning on day 3, mice were paired for $8 \mathrm{~d}$ for $30 \mathrm{~min} / \mathrm{d}$, with the saline group receiving injections on both sides of the boxes, and the drug-paired group receiving intraperitoneal cocaine $(10$ or $20 \mathrm{mg} / \mathrm{kg}$ ) on the white side and saline on the black side. During the testing phase on day 11 , all mice were given a saline injection and were allowed to explore freely for $20 \mathrm{~min}$ and time spent on each side was recorded. The extinction training phase lasted for $30 \mathrm{~min} / \mathrm{d}$ for up to $22 \mathrm{~d}$, and all mice were given saline injections on both sides of the boxes. On extinction test days, all mice were allowed to explore freely for $20 \mathrm{~min}$, and the time spent on each side was recorded. On the reinstatement test day that followed the last extinction test day, all mice were injected with cocaine $(10 \mathrm{mg} / \mathrm{kg}$, i.p.) or saline immediately before being placed in the testing chamber as above for 20 min. Time spent on each side was recorded. The data were analyzed and expressed as time spent on the saline-paired side subtracted from time spent on the drug-paired side. Two-way ANOVA followed by post hoc Bonferroni-Dunn test were used to statistically evaluate the behavioral results.

\section{Results \\ Generation and characterization of mice carrying a Fos mutation in $\mathrm{D}_{1}$ receptor-expressing neurons}

To investigate how c-Fos might function to mediate cocaine-induced persistent neurobiological changes, we used a Cre/ loxP-mediated DNA deletion strategy to make mice with a selective Fos deletion in $D_{1}$ receptor-expressing neurons (Tsien et al., 1996; Zhang et al., 2002b). We made Cre transgenic mice in which Cre expression is driven by the $8 \mathrm{~kb}$ pair promoter of the $D_{1}$ receptor gene that has been shown to be sufficient to drive normal $\mathrm{D}_{1}$ receptor expression in transgenic mice (Dracheva et al., 1999) (Fig. 1A). We identified six lines of founder mice by genomic Southern blotting (Fig. 1B, bottom). We crossed each of the six Drd1-Cre mouse lines with a mouse carrying a $\beta$-actinloxP-stop-loxP-Lac $Z$ transgene that relies on active Cre for $L a c Z$ reporter gene activation (Tsien et al., 1996). To examine the timing and extent of the Cre/loxPmediated DNA deletion, we counted LacZ-expressing neurons and total neurons using sections from multiple brain regions of the double-transgenic offspring over a wide range of ages. Three lines of mice, DCi94 (120), DCi101, and DCi94 (187), exhibited LacZ activity in neurons in all major regions of normal $D_{1}$ receptor expression, including the shell and core of the NAc, CPu, AMG, HIP, and PFC (Missale et al., 1998; Park et al., 2001), starting at 3 weeks of age and reaching peak levels at 7 weeks of age (supplemental Fig. 1, Table 1, available at www.jneurosci.org as supplemental material). Importantly, the reporter gene was poorly activated in these lines of mice between 7 and 28 weeks of age in brain regions in which the $\mathrm{D}_{1}$ receptor gene is not highly expressed, such as the cerebellum (supplemental Table 1, available at www.jneurosci.org as supplemental material).

We crossed the DC94 (120) Drd1-Cre transgenic mouse line with a mouse carrying floxed Fos alleles ( $f / f-F o s$ ) (Zhang et al., 2002b) to obtain mice carrying homozygous floxed Fos and the Cre transgene (Fig. $1 \mathrm{~B}$, designated as $f / f-F o s-D_{1}-C r e$ ). To verify the Fos mutation in $\mathrm{D}_{1}$ receptor-containing neurons, we performed immunostaining for c-Fos. We found that the acute c-Fos induction by a $D_{1}$ receptor agonist SKF81297 was greatly reduced in the $\mathrm{CPu}$ and NAc of $f / f-F o s-D_{1}-\mathrm{Cre}$ mice 7 weeks of age or older compared with that in wild-type mice (Fig. 1C,E, left), indicating that Fos is effectively deleted in $\mathrm{D}_{1}$ receptor-expressing neurons in these mice. The acute c-Fos induction by cocaine was also greatly reduced in the $\mathrm{CPu}$ and NAc (Fig. $1 D, E$, right) in $f / f-F o s-D_{1}-C r e$ mice. To further verify the specificity of the Fos mutation in $\mathrm{D}_{1}$ receptor-containing neurons, we performed coimmunostaining for dynorphin, which colocalizes significantly with the $\mathrm{D}_{1}$ receptor particularly in the dorsal striatum (Xu et al., 1994a; Moratalla et al., 1996a,b; Zhang et al., 2004), and at the same time with c-Fos, which is induced by cocaine in $D_{1}$ 
receptor-expressing neurons (Moratalla et al., 1996a; Zhang et al., 2002a, 2004). In the $\mathrm{NAc}$ and $\mathrm{CPu}$, dynorphin expression was qualitatively unaffected by the Fos mutation (Fig. 1F). In contrast, although dynorphin and c-Fos were coexpressed in striatal neurons in wild-type mice, little c-Fos was induced by an acute cocaine injection in dynorphin-positive striatal neurons (Fig. 1G). These results indicate that Fos expression is essentially eliminated in $D_{1}$ receptor-expressing neurons in $f / f-$ Fos- $D_{1}-$ Cre mice.

To examine whether the Fos mutation is primarily limited to $D_{1}$ receptorexpressing neurons, we treated both $f / f-$ Fos- $D_{1}-$ Cre and wild-type mice between 7 and 28 weeks of age with the $\mathrm{D}_{2}$ class receptor antagonist haloperidol that can induce robust Fos expression in the $\mathrm{CPu}$ (Moratalla et al., 1996b). Both groups of mice exhibited marked catalepsy (Moratalla et al., 1996b) after haloperidol injections, and no behavioral differences were found between wild-type and $f / f-F o s-D_{1}-$ Cre mice (data not shown). Importantly, Fos was induced abundantly by haloperidol in the CPu in both groups of mice, with mutant mice exhibiting 8 and 9\% reductions of c-Fos compared with the wild-type mice at the 0.5 and $2 \mathrm{mg} / \mathrm{kg}$ doses (Fig. 2A). Kainic acid, which elicits widespread c-Fos expression in many brain regions (Zhang et al., 2002b), induced similar levels of c-Fos in brain regions in which the $\mathrm{D}_{1}$ receptor is poorly or not expressed, including the cingulate cortex, entorhinal cortex, median eminence, and VTA in the two groups of mice (Fig. $2 B$ ). Together, these results suggest that the Fos mutation is primarily limited to the $\mathrm{D}_{1}$ receptor-expressing neurons in the age range we used.

$f / f-F o s-D_{1}-$ Cre mice appear healthy with no detectable abnormalities in the brain (supplemental Fig. 2, available at www. jneurosci.org as supplemental material). Acute locomotor responses induced by two doses of $\mathrm{D}_{1}$ or $\mathrm{D}_{2}$ receptor agonists were similar between wild-type and mutant mice (Fig. 3).

\section{c-Fos regulates IEG expression and AP-1 transcription complex formation in the NAc and $\mathrm{CPu}$ after repeated cocaine injections}

c-Fos-regulated gene expression may mediate cocaine-induced neuroadaptation (Graybiel et al., 1990; Morgan and Curran, 1991; Moratalla et al., 1996b). To test this notion, we first investigated how c-Fos regulates the expression of other IEGs before and after cocaine injections. No baseline difference in IEG expression in the NAc and CPu was found in the two groups of mice (Fig. 4) (supplemental Fig. 3, available at www.jneurosci.org as supplemental material) ( $p>0.05)$, suggesting that the Fos mutation did not lead to obvious baseline compensatory changes by other Fos family proteins in $\mathrm{D}_{1}$ receptor-expressing neurons. An acute cocaine injection increased FosB and Fra-2 expression by twofold and fivefold, respectively, in the NAc and CPu in wildtype mice, whereas such induction was attenuated in $\mathrm{f} / \mathrm{f}-\mathrm{Fos}-\mathrm{D}_{1}-$ Cre mice (Fig. 4) (supplemental Fig. 3, available at www.jneurosci.org as supplemental material) $(p<0.05)$. After $7 \mathrm{~d}$ of cocaine injections, FosB and $\Delta$ FosB expression was increased by 1.5 - and
3 -fold, respectively, in wild-type mice, whereas it was 30 and $65 \%$ lower, respectively, in the NAc and CPu in $f / f-F o s-D_{1}-C r e$ mice compared with that in wild-type mice (Fig. 4$)(p<0.05)$. The expression of other IEGs was comparable in the two groups of mice (supplemental Fig. 3, available at www.jneurosci.org as supplemental material) $(p>0.05)$.

c-Fos regulates target gene expression via AP-1 transcription complexes (Morgan and Curran, 1991). The lack of Fos and the consequent changes in FosB and $\Delta$ FosB expression may affect the level and composition of the AP- 1 complexes in $f / f-F o s-D_{1}-C r e$ mice compared with those in wild-type mice before and after exposure to cocaine. Gel-shift analysis indicated that, although baseline levels are similar, $f / f-F o s-D_{1}-C r e$ mice exhibit a $40 \%$ reduction in the level of AP-1 transcription complexes compared with wild-type mice after acute cocaine injections (supplemental Fig. 4, available at www.jneurosci.org as supplemental material). Antibody super shift showed that, as judged by the ratio between the super shifts and regular shifts, there were less FosB $/ \Delta$ FosB in $\mathrm{AP}-1$ complexes in the NAc and $\mathrm{CPu}$ in $f / f-F o s-D_{1}-$ Cre mice compared with that in wild-type mice after both acute $(0.2: 1$ vs $0.8: 1$ ) and repeated (1:1 vs 4:1) cocaine challenges (supplemental Fig. 4, available at www.jneurosci.org as supplemental material). These results indicate that the lack of Fos in $\mathrm{D}_{1}$ receptorexpressing neurons affects FosB and $\Delta$ FosB expression and AP-1 transcription complexes in the $\mathrm{NAc}$ and $\mathrm{CPu}$ after cocaine administration.

\section{c-Fos coordinates additional target gene expression in the $\mathrm{NAc}$ and $\mathrm{CPu}$ after repeated cocaine administration}

The changed dynamic regulation of AP-1 transcription complexes attributable to the Fos deficiency may alter target gene expression in the NAc and $\mathrm{CPu}$ before and after exposure to cocaine. We analyzed the expression of two classes of genes that contain AP-1 binding sites in their promoter regions to test this notion. One class encodes the glutamate receptors (GluRs) that 


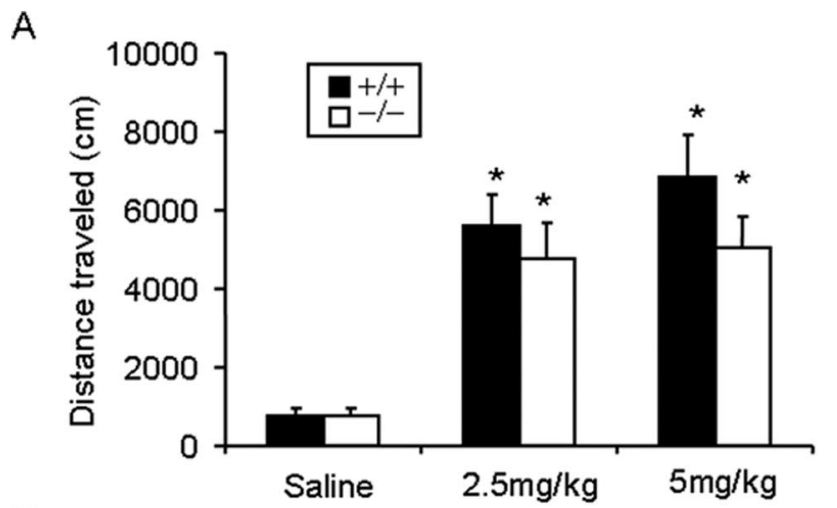

$\mathrm{B}$

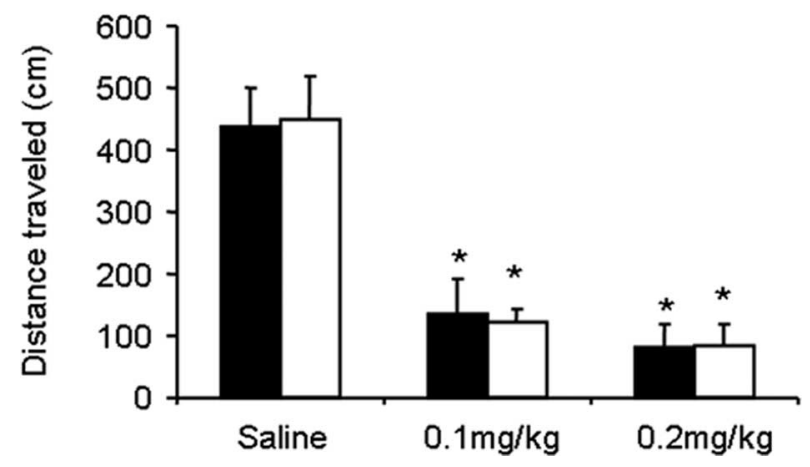

Figure 3. $f / f-F o s-D_{1}-C r e$ and wild-type mice exhibit similar locomotor responses after acute $D_{1}$ and $D_{2}$ receptor agonists injections. $A, B$, Mice were habituated for $1 \mathrm{~h}$ before saline, $D_{1}$ receptor agonist ( $\boldsymbol{A}$, SKF81297) or $D_{2}$ receptor agonist ( $\boldsymbol{B}$, quinpirole) injections (intraperitoneal). Locomotor activities were recorded for $1 \mathrm{~h}$ immediately after injections. $A, n=7$ mice each in the wild-type group, $n=8$ each mice in the mutant group $(-/-) \cdot p>0.05\left(F_{(1,44)}=\right.$ $1.988)$ between genotypes; ${ }^{*} p<0.05\left(F_{(2,44)}=21.672\right)$ between different doses. $\boldsymbol{B}$, Saline wild-type group, $n=10$; saline mutant group, $n=14 ; 0.1 \mathrm{mg} / \mathrm{kg}$ wild-type group, $n=10 ; 0.1$ $\mathrm{mg} / \mathrm{kg}$ mutant group, $n=14 ; 0.2 \mathrm{mg} / \mathrm{kg}$ wild-type group, $n=7 ; 0.2 \mathrm{mg} / \mathrm{kg}$ mutant group, $n=7 . p>0.05\left(F_{(1,61)}=0.54\right)$ between genotypes; ${ }^{*} p<0.05\left(F_{(2,61)}=9.061\right)$ between different doses. There is no statistical difference between wild-type and mutant mice at any dose.

mediate excitatory neural transmission. Blockade of the NMDA receptor 1 subunit (NR1) can attenuate stimulant-induced behavioral sensitization (Wolf, 1998; White and Kalivas, 1998). Persistent $\Delta$ FosB expression or repeated cocaine injections can induce the AMPA receptor subunit 2 (GluR2) expression in the NAc (Kelz et al., 1999), and extinction of cocaine selfadministration can upregulate GluR2 and reduce cocaineseeking behaviors (Sutton et al., 2003). Western blotting indicated that 7 or 28 consecutive days of repeated cocaine injections led to a 1.3- to 1.5-fold increase in NR1 and GluR2 expression in both the NAc and CPu of wild-type mice, yet such induction was attenuated in the $f / f-$ Fos $-D_{1}$-Cre mice (Fig. $\left.5 A, B\right)(p<0.05)$. Basal expression of the two genes was identical in the two groups of mice (Fig. $5 A, B)(p>0.05)$. The expression of NR2A, NR2B, and GluR1 was not different in the two groups of mice before and after cocaine injections (data not shown).

A second gene class encodes signaling molecules $\beta$-catenin, Cdk5, and p35. $\beta$-Catenin functions in intercellular junctions and in the Wnt (wingless-type MMTV integration site family) signaling pathway, and it is induced via $D_{1}$ receptors in the NAc and CPu by cocaine (Zhang et al., 2002a). Cdk5 mediates neurite outgrowth and modulates cocaine-induced behavior and increase in dendritic spine density in the NAc (Bibb et al., 2001). Cdk5 activity is tightly regulated by p35 (Dhavan and Tsai, 2001). We found that repeated cocaine injections increased the expres-
A

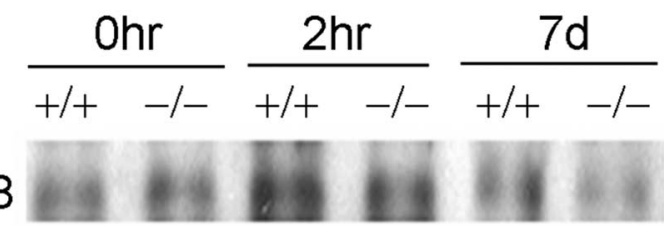

$\Delta \mathrm{FosB}$

B

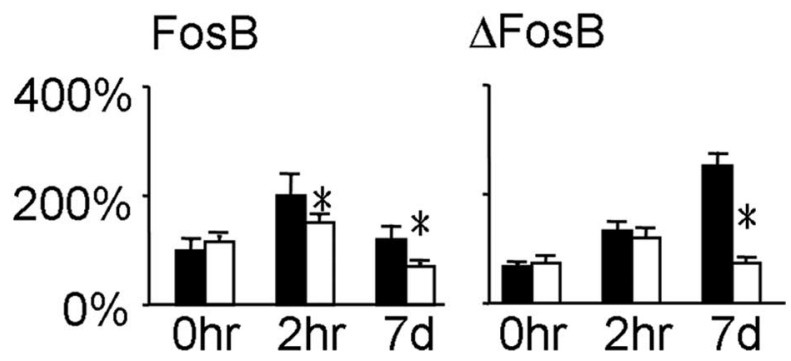

Figure 4. c-Fos regulates cocaine-induced FosB and $\Delta$ FosB expression. We isolated nuclear extracts from the NAc and CPu together from individual wild-type $(+/+)$ and $f / f-F o s-D_{1}-C r e$ $(-/-)$ mouse ( $n=4-7$ mice for each time point) after saline ( $0 \mathrm{~h})$ and $2 \mathrm{~h}(2 \mathrm{~h} ; 30 \mathrm{mg} / \mathrm{kg})$ or $7 \mathrm{~d}(7 \mathrm{~d} ; 20 \mathrm{mg} / \mathrm{kg})$ after cocaine injections. $\boldsymbol{A}$, Western blotting for FosB and $\Delta$ FosB using extracts from each mouse. $B$, Quantification of FosB and $\Delta$ FosB levels with saline-treated wild type as $100 \%$ controls. Filled columns and open columns represent data from wild-type and mutant mice, respectively. Data show mean \pm SEM. ${ }^{*} p<0.05\left(F_{(1,33)}=7.32\right)$ between genotypes.

sion of $\beta$-catenin and $\mathrm{p} 35$ by 1.3 - to 1.7 -fold in both the NAc and the $\mathrm{CPu}$ of wild-type mice, whereas such increases were attenuated in $f / f-F o s-D_{1}-$ Cre mice (Fig. $\left.5 A, B\right)(p<0.05)$. Cdk5 expression was different by 1.3 -fold in the two groups of mice after $28 \mathrm{~d}$ but not $7 \mathrm{~d}$ of cocaine injections (Fig. $5 A, B$ ). Basal expression of the three genes was also identical in the two groups of mice (Fig. 5A,B) ( $p>0.05)$.

To examine further whether Fos regulates Grin1 (NR1), Gria2 (GluR2), Ctnnb ( $\beta$-catenin), Cdk5r1 ( $p 35)$, and $C d k 5$ expression, we transfected three cell lines with Fos and measured the endogenous expression of these genes. Consistent with those observed in vivo, an increasing level of c-Fos increased the expression of Grin1, Gria2, Ctnnb, and Cdk5r1 in vitro (Fig. 5C). Together, these results indicate that c-Fos regulates the expression of these target genes both in vivo and in vitro.

c-Fos mediates changes in medium spiny neuron dendritic morphology induced by repeated exposure to cocaine

Repeated cocaine exposure alters the number of dendrites and the density of dendritic spines of neurons in the NAc and cortex (Robinson and Kolb, 1999; Norrholm et al., 2003). This dendritic remodeling may reflect neuronal circuit reorganization and contribute to the persistence of cocaine-induced behaviors. To investigate whether Fos mediates baseline and cocaine-induced persistent neuronal morphological changes, we treated both $f / f-$ Fos- $D_{1}-$ Cre and wild-type mice with saline or cocaine for 28 consecutive days and performed dendritic morphological analysis. Repeated cocaine injections led to an increase in dendritic branching on medium spiny neurons in the NAc shell (Fig. $6 A, D)\left(14.0 \pm 0.89\right.$ vs $\left.10.3 \pm 0.95 ;{ }^{*} p<0.05\right)$ and $\mathrm{CPu}$ (Fig. $6 B, D)\left(16.2 \pm 0.79\right.$ vs $\left.11.6 \pm 0.25 ;{ }^{*} p<0.05\right)$ compared with saline injections in control mice yet failed to do so in $f / f-F o s-D_{1}-$ Cre mice (Fig. 6A, $B, D)(\mathrm{NAc}, 10.3 \pm 0.95$ vs $11.0 \pm 0.65$; CPu, $12.0 \pm 0.85$ vs $11.8 \pm 0.31 ; p>0.05)$. Repeated cocaine injections also induced an increase in dendritic spine density on medium 
spiny neurons in the NAc shell (Fig. 6C,D) $\left(14.8 \pm 0.17\right.$ vs $\left.10.6 \pm 0.39 ;{ }^{*} p<0.05\right)$ and $\mathrm{CPu}$ (Fig. 6C,D) (16.0 \pm 0.52 vs $10.3 \pm$ 0.34 ; $\left.{ }^{\#} p<0.05\right)$ compared with saline injections in wild-type mice but not in $f / f-$ Fos $-D_{1}-$ Cre mice (Fig. 6C,D) (NAc, $10.0 \pm 0.80$ vs $9.9 \pm 0.77 ; \mathrm{CPu}, 11.2 \pm 0.65$ vs $10.4 \pm 0.33 ; p>0.05)$. Although there was no baseline difference, both the number of dendrites and density of dendritic spines of neurons in the NAc shell and $\mathrm{CPu}$ were significantly different between the two groups of mice after repeated cocaine injections (Fig. $6 A-D)(p<0.05)$. These results indicate that, unlike in wildtype mice, $f / f-F o s-D_{1}-$ Cre mice no longer exhibit increased dendritic branching and dendritic spine density in response to repeated cocaine administration.

\section{c-Fos contributes to cocaine-induced behavioral sensitization}

Persistent changes in gene expression and dendritic morphology induced by repeated cocaine administration may contribute to long-lasting behavioral changes such as behavioral sensitization (Kalivas et al., 1998; Robinson and Berridge, 2000). We investigated the potential contribution of c-Fos in this process by treating $f / f-F o s-$ $D_{1}-$ Cre and wild-type mice either acutely or once daily with two different doses of cocaine for 7 consecutive days and again after $72 \mathrm{~h}$ (Fig. 7). Although there were no differences in baseline activity after saline injections between mutant mice and wildtype mice, acute cocaine treatment at the $20 \mathrm{mg} / \mathrm{kg}$ dose induced significant locomotion compared with saline injections, and repeated cocaine injections at both the 10 and $20 \mathrm{mg} / \mathrm{kg}$ doses induced behavioral sensitization in wild-type but not in $f / f-$ Fos $-D_{1}$-Cre mice (Fig. 7). Repeated saline treatment did not induce appreciable changes in locomotor activity in wild-type and $f / f-F o s-D_{1}-$ Cre mice $(n=8$ mice each; data not shown). This result suggests that c-Fos contributes to both the acute locomotor response to $20 \mathrm{mg} / \mathrm{kg}$ cocaine treatment as well as the development of behavioral sensitization to cocaine at both the 10 and $20 \mathrm{mg} / \mathrm{kg}$ doses in the injection paradigms we used.

Wild-type and $f / f-F o s-D_{1}-$ Cre mice did not show basal differences in rearing $(1.0 \pm 0.0$ vs $0.7 \pm 0.20$; $p>0.05)$ and grooming $(1.1 \pm 0.15$ vs $1.0 \pm 0.0 ; p>0.05)$. Acute cocaine treatment at the $20 \mathrm{mg} / \mathrm{kg}$ dose induced rearing in both groups of mice $(p<0.05)$, with wild-type mice exhibiting more rearing than $f / f-F o s-D_{1}-C r e$ mice $(p<0.05)$. In contrast, grooming behavior was not induced by acute cocaine injections in either group of mice $(p>0.05)$. After repeated cocaine injections at the $20 \mathrm{mg} / \mathrm{kg}$ dose, wild-type (chronic vs acute cocaine, $4.4 \pm 0.27$ vs $2.6 \pm 0.27 ; p<0.05$ ) but not $f / f-F o s-D_{1}-C r e$

A

B

C
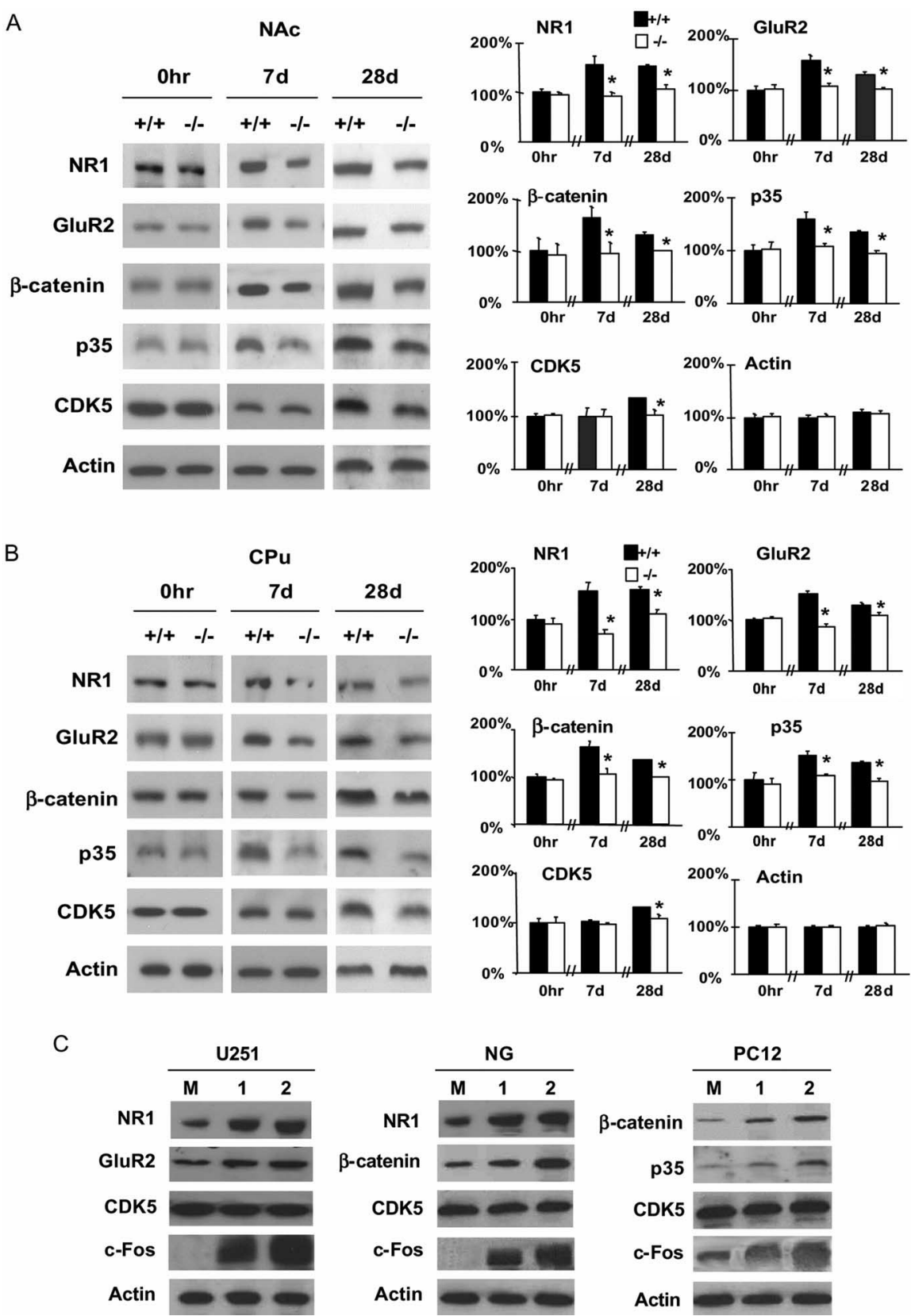

Figure 5. $\quad \boldsymbol{A}, \boldsymbol{B}, \mathrm{c}-$ Fos coordinates target gene expression. We isolated whole-cell extracts from the NAC $(\boldsymbol{A})$ and $\mathrm{CPu}(\boldsymbol{B})$ of wild-type $(+/+)$ and $f / f-F o s-D_{1}-C r e(-/-)$ mouse after saline ( 0 ; $n=4$ mice each), 7 ( $7 \mathrm{~d} ; n=7$ mice each), or 28 consecutive days (28d; $n=5+1+$ and $7-1-$ mice) of cocaine injections at the $20 \mathrm{mg} / \mathrm{kg}$ dose. We performed Western blotting for the indicated proteins and quantified gene expression levels with saline-treated wild type as $100 \%$ controls. Data represent mean \pm SEM. ${ }^{*} p<0.05$ (for NAc and $C P u, F_{(1,33)}=34.26$ and 24.68 for NR1; $F_{(1,33)}=37.71$ and 48.19 for GluR2; $F_{(1,33)}=11.06$ and 27.52 for $\beta$-catenin; $F_{(1,33)}=23.23$ and 34.67 for $p 35 ; F_{(1,33)}=12.10$ and 38.20 for $(\mathrm{dk} 5)$ between genotypes. $C$, Increasing amounts of Fos (1 and 2) were transfected into various cells in duplicates with mock-transfected cells (M) as controls. Whole-cell extracts were used for Western blotting. (chronic vs acute cocaine, $1.3 \pm 0.20$ vs $1.3 \pm 0.20 ; p<0.05$ ) mice developed sensitized rearing compared with that after the first cocaine injection. Both wild-type (chronic vs acute cocaine, $2.4 \pm$ 0.27 vs $1.4 \pm 0.27$ ) and $f / f-F o s-D_{1}-C r e$ (chronic vs acute cocaine, $2.4 \pm 0.21$ vs $1.4 \pm 0.21)$ mice developed sensitized grooming behaviors $(p<0.05)$, and there was no difference between the two groups of mice $(p>0.05)$. At the cocaine dose used, we did not observe obvious stereotyped behaviors such as headbobbing, nail biting, taffy pulling, repetitive sniffing, and circling. 
A

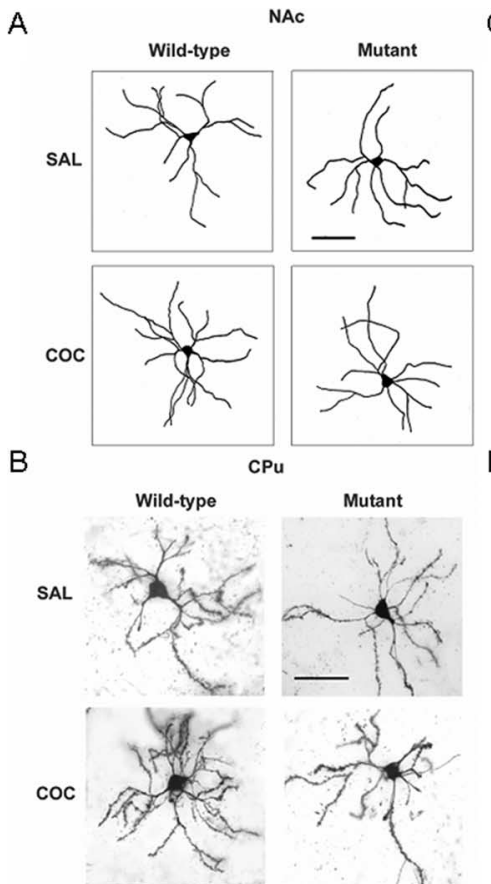

C
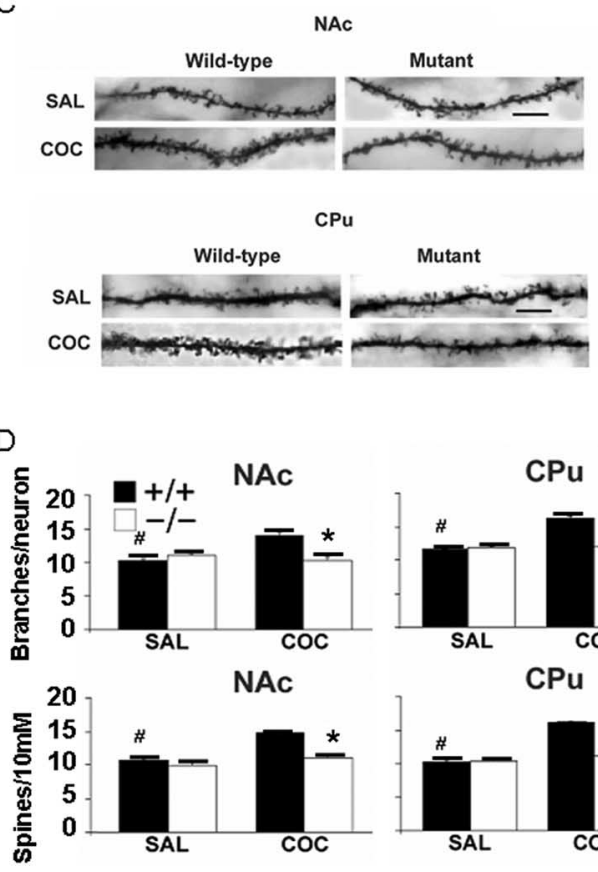

the persistence and extinction of the reinforcing effects of cocaine remains unknown. We investigated this issue by performing a CPP study (Tzschentke, 1998). Neither $f / f-F o s-D_{1}-C r e$ nor wild-type mice showed bias in exploring the two compartments (Fig. $8 A$ ) ( $p>0.05)$. After $8 \mathrm{~d}$ of alternating cocaine and saline injections, both $f / f-F o s-D_{1}-C r e$ and wild-type mice exhibited CPP behaviors at both cocaine doses compared with saline groups (Fig. $8 A)(p<0.05)$, and there was no difference in the induction of the CPP behavior between wild-type and $f / f-F o s-D_{1}-$ Cre mice $(p>0.05)$. Wild-type mice showed extinction of CPP behaviors after 12 (and 16) d of extinction training (Fig. $8 B)(p>0.05)$. In contrast, $f / f-F o s-D_{1}-$ Cre mice did not show extinction of CPP behaviors until after $22 \mathrm{~d}$ of training (Fig. $8 B)(p>0.05)$. After $16 \mathrm{~d}$ of extinction training, wild-type exhibited cocainereinstated CPP behaviors, and, after $22 \mathrm{~d}$ of extinction training, both wild-type and f/f-Fos $-D_{1}-$ Cre mice exhibited cocaineinduced (Fig. 8C) $(p<0.05)$ but not saline-induced (data not shown) reinstatement of CPP behaviors. These results suggest that $f / f-F o s-D_{1}-C r e$ mice exhibit more persistent memory for the reinforcing effects of cocaine than wild-type control mice.

\section{Discussion}

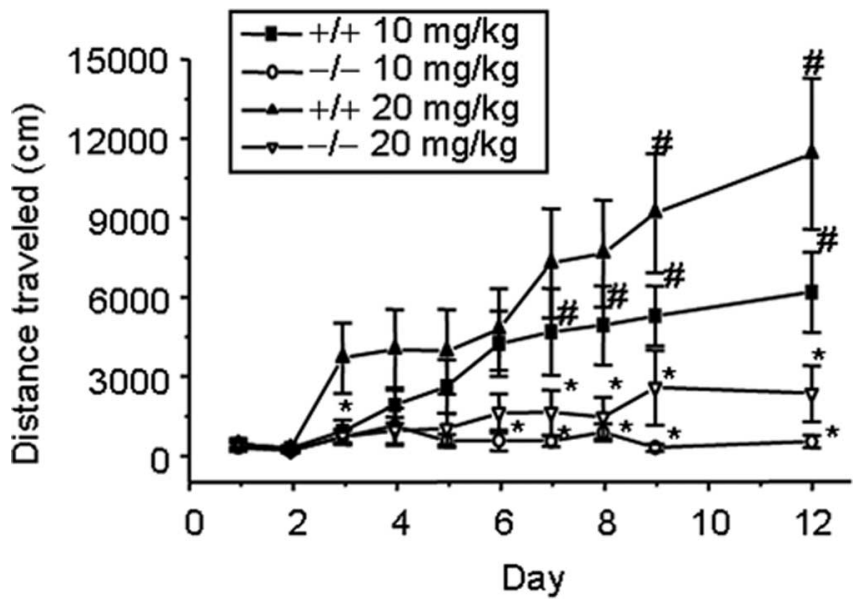

Figure 7. c-Fos contributes to cocaine-induced behavioral sensitization. We recorded locomotor activity of $f / f-F o s-D_{1}-$ Cre $(-/-; n=9$ and 8 for 10 and $20 \mathrm{mg} / \mathrm{kg}$ of cocaine) and wild-type ( $+/+; n=10$ and 8 for 10 and $20 \mathrm{mg} / \mathrm{kg}$ of cocaine) mice on days $1-9$ and on day 12 for 60 min before and after the injections. ${ }^{*} p<0.05$ compared with same dose wild-type mice; ${ }^{\prime} p<0.05$ compared with day 3 . The $F$ values from day 1 through day 9 and day 12 are as follows: $F_{(1,33)}=2.537, F_{(1,33)}=0.639, F_{(1,33)}=4.73, F_{(1,33)}=4.939, F_{(1,33)}=7.003$, $F_{(1,33)}=10.151, F_{(1,33)}=9.874, F_{(1,33)}=16.259, F_{(1,33)}=13.909$, and $F_{(1,33)}=10,875$.

c-Fos facilitates the extinction of cocaine-induced CPP Cocaine produces powerful reinforcing effects that are difficult to extinct (Wise, 2000; Dackis and O'Brien, 2005). $D_{1}$ receptors have been implicated in mediating such behavioral effects, yet whether Fos-mediated intracellular mechanisms contribute to
Repeated exposure to cocaine can induce persistent changes in behavior and neuronal circuits via $\mathrm{DA} \mathrm{D}_{1}$ receptors that are difficult to extinct. Although c-Fos is a transcription factor that is robustly induced above basal levels by $\mathrm{D}_{1}$ receptor agonists and cocaine in $\mathrm{D}_{1}$ receptor-expressing neurons, whether such induction plays a major role in modulating any neuronal responses to $\mathrm{D}_{1}$ receptor activation is unknown. To investigate this issue, we engineered and analyzed a mouse in which Fos is primarily mutated in $D_{1}$ receptor-expressing neurons. Our findings suggest that Fos regulates cocaine-induced reorganization of neuronal circuits, alteration in gene expression, the development and manifestation of behavioral sensitization, and to the extinction of cocaine-induced reinforcing effects.

The $\mathrm{D}_{1}$ receptor neuron-specific Fos mutant mouse model We made a mouse carrying a Fos mutation in $\mathrm{D}_{1}$ receptorexpressing neurons using Cre/loxP-mediated DNA deletion. We found that SKF81297- and cocaine-induced c-Fos expression is significantly reduced in the $\mathrm{CPu}$ and NAc in $f / f-F o s-D_{1}-$ Cre mice compared with that in wild-type mice. Although dynorphin expression is qualitatively unaffected, cocaine-induced Fos expression is significantly reduced in dynorphin-positive neurons in the $\mathrm{CPu}$ and NAc in $f / f-F o s-D_{1}-$ Cre mice compared with those in wild-type mice. Importantly, haloperidol induced abundant c-Fos expression in the $\mathrm{CPu}$ in $f / f-F o s-D_{1}-C r e$ and wild-type mice. The $8-9 \%$ reduction in Fos expression in $f / f-F o s-D_{1}-C r e$ mice is possibly attributable to Fos mutation in $\mathrm{D}_{1}$ receptorexpressing neurons that also coexpress $\mathrm{D}_{2}$ receptors. Kainic acidinduced Fos expression is similar in the two groups of mice in 


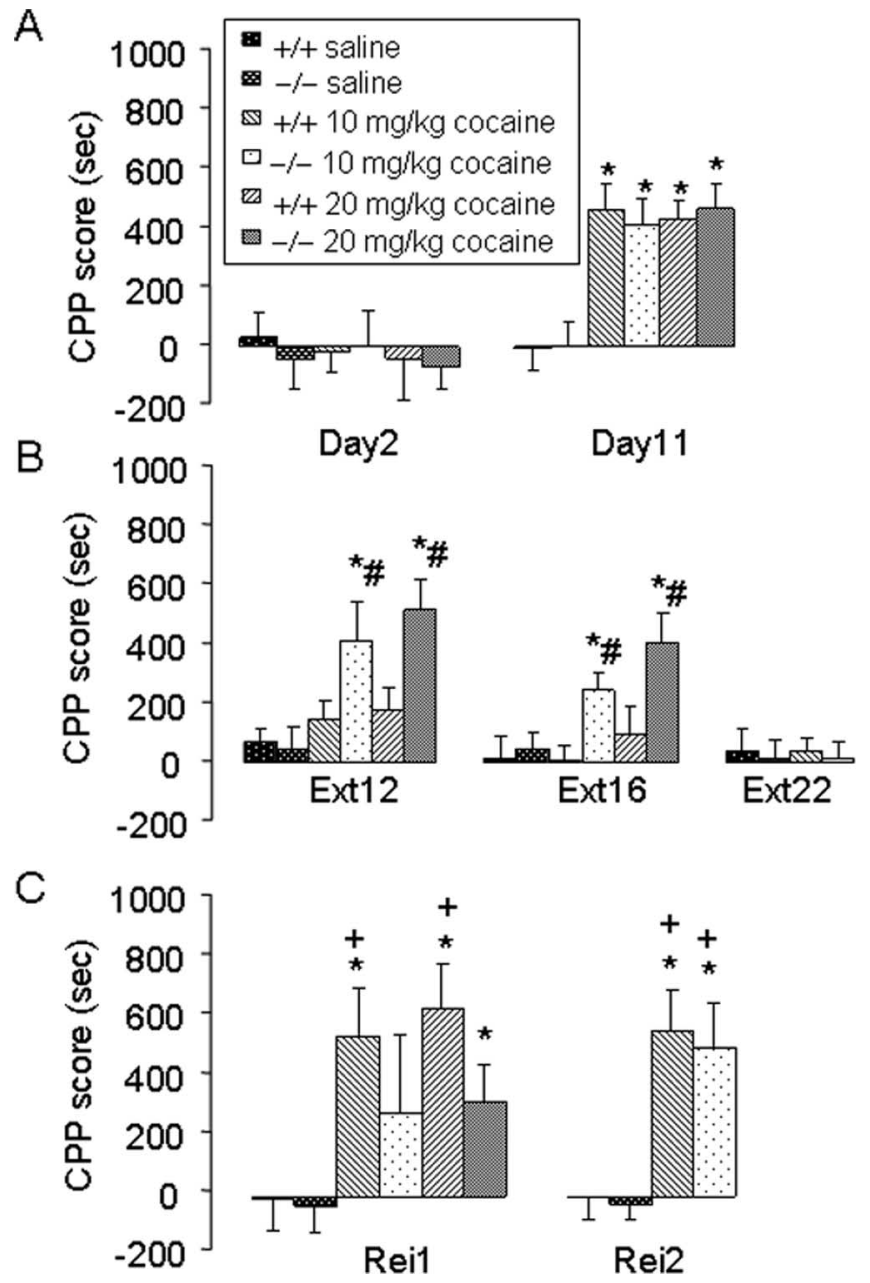

Figure 8. c-Fos facilitates the extinction of cocaine-induced (PP. A, Induction of CPP behaviors. Mice ( $n=8$ per group) were allowed to explore in CPP boxes and were then given $8 \mathrm{~d}$ of training at the indicated drug doses before being tested for the induction of (PP behaviors on day 11. B, Extinction of CPP behaviors. Extinction (Ext) training was conducted for $16 \mathrm{~d}$ for the 20 $\mathrm{mg} / \mathrm{kg}$ and $22 \mathrm{~d}$ for the $10 \mathrm{mg} / \mathrm{kg}$ cocaine groups, respectively, and behaviors were tested after 12,16 , or $22 \mathrm{~d}$ of training. C, Reinstatement of CPP behaviors. Mice were given a $10 \mathrm{mg} / \mathrm{kg}$ intraperitoneal injection of cocaine and were allowed to explore CPP boxes after either $16 \mathrm{~d}$ (Rei1) or $22 \mathrm{~d}$ (Rei2) of extinction training. Data show mean \pm SEM time spent in the drugpaired side minus the saline-paired side. ${ }^{*} p<0.05\left(F_{(2,47)}=21.12\right.$ on day $11 ; F_{(2,47)}=5.92$ on extinction day $12 ; F_{(2,47)}=4.26$ on extinction day $16 ; F_{(2,47)}=5.86$ on reinstatements day 1 ; $F_{(2,47)}=21.22$ on reinstatements day 2$)$ drug-paired groups compared with saline-paired groups. ${ }^{\#} p<0.05\left(F_{(2,47)}=7.57\right.$ on extinction day 12 and $F_{(2,47)}=9.97$ on extinction day 16$)$ compared with wild-type mice for the same drug dose and day. ${ }^{+} p<0.05\left(F_{(2,47)}=2.40\right.$ on reinstatements day 1 and $F_{(1,31)}=0.098$ on reinstatements day 2) compared with the same group of mice and drug dose after 16 or $22 \mathrm{~d}$ of extinction training, respectively.

brain areas that express $\mathrm{D}_{1}$ receptors poorly. These results indicate that the Fos mutation is primarily limited to $\mathrm{D}_{1}$ receptorexpressing neurons in $f / f-F o s-D_{1}-C r e$ mice within the $7-28$ week age range.

Unlike $\mathrm{D}_{1}$ receptor mutant mice (Xu et al., 1994a,b), f/f-Fos$D_{1}$-Cre mice exhibit apparent normal development with baseline motor activity, similar acute locomotor responses to SKF81297, quinpirole and haloperidol treatment, and similar baseline dendritic structures and dendritic spine density compared with wildtype mice. There are no detectable abnormalities in the brains of $f / f-F o s-D_{1}-C r e$ mice. Basal IEG expression levels and basal and cocaine-induced expression of dynorphin are also similar in $f / f-$ Fos $-D_{1}-$ Cre and wild-type mice. These results suggest that Fos mutation did not noticeably affect the development of the DA system in $f / f-F o s-D_{1}$-Cre mice.

\section{c-Fos mediates cocaine-induced dendritic morphological changes}

Drug-induced dendritic remodeling may reflect changes in neuronal circuits including synaptic strength and connections (Robinson and Kolb, 1999). Both $\mathrm{D}_{1}$ and $\mathrm{D}_{2}$ receptor-expressing neurons exhibit changed dendritic morphology after chronic exposure to cocaine, although the dendritic spine formation is only stable and long lasting in $\mathrm{D}_{1}$ receptor-expressing neurons (Lee et al., 2006). We found that the Fos deficiency in $\mathrm{D}_{1}$ receptorexpressing neurons results in attenuation in chronic cocaineinduced increases in dendritic branching and dendritic spine density in the NAc and $\mathrm{CPu}$ in $f / f-F o s-D_{1}-$ Cre mice without affecting basal dendritic morphology. This result suggests that it is the repeated transient upregulation of c-Fos by cocaine rather than basal c-Fos that is involved in dendritic remodeling. Noticeably, the lack of obvious dendritic remodeling in $\mathrm{f} / \mathrm{f}-\mathrm{Fos}-\mathrm{D}_{1}-\mathrm{Cre}$ mice resembles that of the $D_{1}$ receptor mutant mice after repeated cocaine administration $(\mathrm{Z}$. Ren and $\mathrm{Xu}$, unpublished observation), suggesting that these molecules may be in the same pathway in mediating cocaine-induced dendritic remodeling. Inhibiting Cdk5 activity attenuates cocaine-induced increase in dendritic spine density (Norrholm et al., 2003). We found that c-Fos can upregulate p35 and Cdk5 expression in the NAc and $\mathrm{CPu}$ after $28 \mathrm{~d}$ of cocaine treatment, and the time course for such regulation correlates with dendritic remodeling. Although Cdk5 levels are not directly affected by changes in the levels of c-Fos after $7 \mathrm{~d}$ of cocaine injections, the changed p35 levels may lead to changes in Cdk5 activity. Together, our findings suggest that, during repeated exposure to cocaine, c-Fos functions in $D_{1}$ receptor-expressing neurons to mediate signaling events, leading to dendritic reorganization that may contribute to the persistence of drug addiction.

\section{c-Fos contributes to the acquisition and extinction of cocaine-induced behavioral changes}

We previously demonstrated that the $\mathrm{D}_{1}$ receptor is necessary for the induction of behavioral sensitization by cocaine (Xu et al., 2000). In the current study, we found that $f / f-F o s-D_{1}-$ Cre mice exhibit attenuated cocaine-induced behavioral sensitization compared with wild-type mice. Moreover, $f / f-F o s-D_{1}-C r e$ mice exhibit less sensitized responses in rearing and comparable grooming compared with wild-type mice after repeated cocaine injections. These results suggest that c-Fos in $\mathrm{D}_{1}$ receptorexpressing neurons is likely required for the development of persistent behavioral changes induced by repeated exposure to cocaine.

The $D_{1}$ receptor mediates the reinforcing effects of cocaine (Caine and Koob, 1994; Tella, 1994; Cervo and Samanin, 1995; Self et al., 1996; Baker et al., 1998; Tzschentke, 1998; Caine et al., 1999, 2000; Katz et al., 1999; Anderson et al., 2003) (Caine, Gabriel, Berkowitz, Gold, Koob, Tonegawa, Zhang, and Xu, unpublished results). Much less is known regarding the intracellular mechanism that mediates the induction and particularly the extinction of such reinforcing effects. We found that, although normal in induction and reinstatement, $f / f-F o s-D_{1}-C r e$ mice exhibit delayed extinction of cocaine-induced CPP behaviors compared with wild-type mice. These results suggest that a c-Fos-regulated molecular mechanism in $\mathrm{D}_{1}$ receptor-bearing neurons is involved in the memory of the reinforcing effects of cocaine. Extinction of cocaine self-administration can upregulate GluR2 ex- 
pression and reduce cocaine-seeking behaviors (Sutton et al., 2003). Significantly, we found that, in the absence of Fos, GluR2 expression is reduced in the NAc and $\mathrm{CPu}$ after repeated cocaine injections. Although we have not directly compared GluR2 expression in the two groups of mice in the context of CPP, an inability to upregulate the expression of GluR2 in the mutant mice during extinction training may contribute to a delayed extinction of cocaine-induced CPP behavior compared with wildtype mice.

We noted that the lack of c-Fos in $\mathrm{D}_{1}$ receptor-expressing neurons markedly attenuated the development of cocaineinduced behavioral sensitization yet did not obviously affect the induction or reinstatement of CPP by cocaine. It is possible that, whereas the $D_{1}$ receptor is important for mediating both the locomotor stimulating and reinforcing effects of cocaine, multiple intracellular mechanisms may be differentially responsible for mediating cocaine-induced diverse behavioral effects (BramiCherrier et al., 2005).

\section{c-Fos likely mediates cocaine-induced persistent changes by regulating AP-1 transcription complexes and target gene expression}

$\Delta$ FosB mediates several key aspects of cocaine actions (Kelz et al., 1999; Nestler, 2001). We found that the c-Fos mutation results in reduced FosB expression after acute cocaine injections and reduced FosB and $\Delta$ FosB expression after repeated cocaine injections in $f / f-F o s-D_{1}-C r e$ mice compared with that in wild-type mice. Moreover, less FosB $/ \Delta$ FosB exist in AP-1 transcription complexes in the NAc and CPu in $f / f-F o s-D_{1}-C r e$ mice compared with wild-type mice after either acute or repeated exposure to cocaine. These findings parallel those found in $\mathrm{D}_{1}$ receptor mutant mice (Zhang et al., 2002a), suggesting that one possible mechanism for c-Fos to mediate cocaine-induced long-lasting changes is to regulate $\Delta \mathrm{FosB}$ expression, and consequently $\Delta$ FosB-regulated target genes, in $\mathrm{D}_{1}$ receptor-bearing neurons. Because c-Fos and $\Delta$ FosB have different half-lives and c-Fos- and $\Delta$ FosB-containing AP-1 complexes have different AP-1 binding affinities, c-Fos likely also regulates a set of target genes that is not regulated by $\Delta$ FosB after exposure to cocaine. We noted that, regardless of their induction status, Fra-1, Fra-2, c-Jun, JunB, and JunD all participate in AP-1 transcription complexes in the NAc and $\mathrm{CPu}$, and the extent of participation of each protein changes with more cocaine injections, suggesting that they may play differential roles in cocaine-induced neuroadaptation.

Although not significantly affecting basal levels, the c-Fos deficiency attenuated Grin1, Gria2, Ctbnn, and Cdk5r1 induction in the NAc and $\mathrm{CPu}$ in vivo by repeated cocaine injections, whereas overexpression of c-Fos upregulated the expression of these genes in vitro. These findings suggest that the attenuated induction of these genes in $f / f-F o s-D_{1}-C r e$ mice compared with wild-type mice after repeated exposure to cocaine is likely attributable to a lack of direct transcriptional regulation mediated by c-Fos rather than to various indirect effects of the Fos mutation. After repeated cocaine injections, the enhanced NR1 and GluR2 expression may change synaptic transmission, whereas the increased $\beta$-catenin and p35 expression may affect neuronal connections in the NAc and $\mathrm{CPu}$.

Our current studies using $f / f-F o s-D_{1}-$ Cre mice demonstrate that the Fos deficiency results in several neurobiological and behavioral phenotypes that parallel those found using $\mathrm{D}_{1}$ receptor mutant mice in the context of cocaine-induced neuroplastic changes. For example, both $\mathrm{D}_{1}$ receptors and c-Fos expressed in $\mathrm{D}_{1}$ receptor-bearing neurons contribute to aspects of the loco- motor stimulating and positive reinforcing effects of cocaine (Xu et al., 1994a,b, 2000) (Caine, Gabriel, Berkowitz, Gold, Koob, Tonegawa, Zhang, and $\mathrm{Xu}$, unpublished results). Moreover, both $\mathrm{D}_{1}$ receptors and c-Fos mediate dendritic remodeling and regulate gene expression induced by cocaine (McClung and Nestler, 2003; Zhang et al., 2004, 2005). Furthermore, a functional $D_{1}$ receptor is required for c-Fos induction by cocaine, and some of cocaine-regulated genes that are mediated by $D_{1}$ receptors are also subject to c-Fos regulation (Drago et al., 1996; Moratalla et al., 1996b; Zhang et al., 2002a, 2004, 2005). These findings support a molecular model in which repeated exposure to cocaine results in repeated transient upregulation of c-Fos expression via $\mathrm{D}_{1}$ receptors. Elevated $\mathrm{c}$-Fos, in turn, integrates mechanisms within $\mathrm{D}_{1}$ receptor-expressing neurons to mediate chronic cocaine-induced expression of cellular genes, reorganization of neuronal circuits, and both the development and the extinction of behavioral responses.

\section{References}

Anderson SM, Bari AA, Pierce RC (2003) Administration of the D1-like dopamine receptor antagonist SCH-23390 into the medial nucleus accumbens shell attenuates cocaine priming-induced reinstatement of drug-seeking behavior in rats. Psychopharmacology 168:132-138.

Baker DA, Fuchs RA, Specio SE, Khroyan TV, Neisewander JL (1998) Effects of intraaccumbens administration of SCH-23390 on cocaineinduced locomotion and conditioned place preference. Synapse 30:181-193.

Bibb JA, Chen J, Taylor JR, Svenningsson P, Nishi A, Snyder GL, Yan Z, Sagawa ZK, Ouimet CC, Nairn AC, Nestler EJ, Greengard P (2001) Effects of chronic exposure to cocaine are regulated by the neuronal protein Cdk5. Nature 410:376-380.

Brami-Cherrier K, Valjent E, Hervé D, Darragh J, Corvol J, Pages C, Simon J, Girault J, Caboche J (2005) Parsing molecular and behavioral effects of cocaine in mitogen- and stress-activated protein kinase-1-deficient mice. J Neurosci 25:11444-11454.

Cabib S, Castellano C, Cestari V, Filibeck U, Puglisi-Allegra S (1991) $D_{1}$ and $\mathrm{D}_{2}$ receptor antagonists differently affect cocaine-induced locomotor hyperactivity in the mouse. Psychopharmacology 105:335-339.

Caine SB, Koob GF (1994) Effects of dopamine D-1 and D-2 antagonists on cocaine-self-administration under different schedules of reinforcement in the rat. J Pharmacol Exp Ther 270:209-218.

Caine SB, Negus SS, Mello NK, Bergman J (1999) Effects of dopamine D1like and D2-like agonists in rats that self-administer cocaine. J Pharmacol Exp Ther 291:353-360.

Caine SB, Negus SS, Mello NK (2000) Effects of dopamine D1-like and D2like agonists on cocaine self-administration in rhesus monkeys: rapid assessment of cocaine dose-effect functions. Psychopharmacology 148:41-51.

Carlezon Jr WA, Thome J, Olson VG, Lane-Ladd SB, Brodkin ES, Hiroi N, Duman RS, Neve RL, Nestler EJ (1998) Regulation of cocaine reward by CREB. Science 282:2272-2275.

Cervo L, Samanin R (1995) Effects of dopaminergic and glutamatergic receptor antagonists on the acquisition and expression of cocaine conditioning place preference. Brain Res 673:242-250.

Dackis C, O'Brien C (2005) Neurobiology of addiction: treatment and public policy ramifications. Nat Neurosci 8:1431-1436.

Dhavan R, Tsai LH (2001) A decade of CDK5. Nat Rev Mol Cell Biol 2:749-759

Dracheva S, Xu M, Kelley KA, Haroutunian V, Holstein GR, Haun S, Silverstein JH, Sealfon SC (1999) Paradoxical locomotor behaviors of dopamine D1 receptor transgenic mice. Exp Neurol 157:169-179.

Drago J, Gerfen CR, Westphal H, Steiner H (1996) D1 dopamine receptordeficient mouse: cocaine-induced regulation of immediate-early gene and substance $\mathrm{P}$ expression in the striatum. Neuroscience 74:813-823.

Everitt BJ, Wolf ME (2002) Psychomotor stimulant addiction: a neural systems perspective. J Neurosci 22:3312-3320.

Graybiel AM, Moratalla R, Robertson HA (1990) Amphetamine and cocaine induce drug-specific activation of the c-fos gene in striosome-matrix compartments and limbic subdivisions of the striatum. Proc Natl Acad Sci USA 87:6912-6916. 
Greengard P, Allen PB, Nairn AC (1999) Beyond the dopamine receptor: the DARPP-32/protein phosphatase-1 cascade. Neuron 23:435-447.

Henry DJ, White FJ (1995) The persistence of behavioral sensitization to cocaine parallels enhanced inhibition of nucleus accumbens neurons. J Neurosci 15:6287-6299.

Hyman SE, Malenka RC (2001) Addiction and the brain: the neurobiology of compulsion and its persistence. Nat Rev Neurosci 2:695-703.

Hyman SE, Malenka RC, Nestler EJ (2006) Neural mechanisms of addiction: the role of reward-related learning and memory. Annu Rev Neurosci 29:565-598.

Kalivas PW, Pierce RC, Cornish J, Sorg BA (1998) A role for sensitization in craving and relapse in cocaine addiction. J Psychopharmacol 12:49-53.

Katz JL, Kopajtic TA, Myers KA, Mitkus RJ, Chider M (1999) Behavioral effects of cocaine: interactions with D1 dopaminergic antagonists and agonists in mice and squirrel monkeys. J Pharmacol Exp Ther 291:265-279.

Kelley AE (2004) Memory and addiction; shared neural circuitry and molecular mechanisms. Neuron 44:161-179.

Kelz MB, Chen J, Carlezon Jr WA, Whisler K, Gilden L, Beckmann AM, Steffen C, Zhang YJ, Marotti L, Self DW, Tkatch T, Baranauskas G, Surmeier DJ, Neve RL, Duman RS, Picciotto MR, Nestler EJ (1999) Expression of the transcription factor deltaFosB in the brain controls sensitivity to cocaine. Nature 401:272-276.

Khroyan TV, Barrett-Larimore RL, Rowlett JK, Spealman RD (2000) Dopamine D1- and D2-like receptor mechanisms in relapse to cocaine-seeking behavior: effects of selective antagonists and agonists. J Pharmacol Exp Ther 294:680-687.

Koob GF (1992) Drugs of abuse: anatomy, pharmacology and function of reward pathways. Trends Pharmacol Sci 13:177-184.

Koob GF, Sanna PP, Bloom FE (1998) Neuroscience of addiction. Neuron 21:467-476.

Kreibich AS, Blendy JA (2004) cAMP response element-binding protein is required for stress but not cocaine-induced reinstatement. J Neurosci 24:6686-6692.

Kumar A, Choi KH, Renthal W, Tsankova NM, Theobald DE, Truong HT, Russo SJ, Laplant Q, Sasaki TS, Whistler KN, Neve RL, Self DW, Nestler EJ (2005) Chromatin remodeling is a key mechanism underlying cocaineinduced plasticity in striatum. Neuron 48:303-314.

Laakso A, Mohn AR, Gainetdinov RR, Caron MG (2002) Experimental genetic approaches to addiction. Neuron 36:213-228.

Lee KW, Kim Y, Kim AM, Helmin K, Nairn AC, Greengard P (2006) Cocaine-induced dendritic spine formation in D1 and D2 dopamine receptor-containing medium spiny neurons in nucleus accumbens. Proc Natl Acad Sci USA 103:3399-3404.

McClung CA, Nestler EJ (2003) Regulation of gene expression and cocaine reward by CREB and DeltaFosB. Nat Neurosci 6:1208-1215.

Missale C, Nash SR, Robinson SW, Jaber M, Caron MG (1998) Dopamine receptors: from structure to function. Physiol Rev 78:189-225.

Moratalla R, Elibol B, Vallejo M, Graybiel AM (1996a) Network-level changes in expression of inducible Fos-Jun proteins in the striatum during chronic cocaine treatment and withdrawal. Neuron 17:147-156.

Moratalla R, Xu M, Tonegawa S, Graybiel AM (1996b) Cellular responses to psychomotor stimulant and neuroleptic drugs are abnormal in mice lacking the D1 dopamine receptor. Proc Natl Acad Sci USA 93:14928-14933.

Morgan JI, Curran T (1991) Stimulus-transcription coupling in the nervous system: involvement of the inducible proto-oncogenes fos and jun. Annu Rev Neurosci 14:421-451.

Nestler EJ (2001) Molecular basis of long-term plasticity underlying addiction. Nat Rev Neurosci 2:119-128.
Norrholm SD, Bibb JA, Nestler EJ, Ouimet CC, Taylor JR, Greengard P (2003) Cocaine-induced proliferation of dendritic spines in nucleus accumbens is dependent on the activity of cyclin-dependent kinase-5. Neuroscience 116:19-22.

Park Y, Ho IK, Fan LW, Loh HH, Ko KH (2001) Region specific increase of dopamine receptor D1/D2 mRNA expression in the brain of mu-opioid receptor knockout mice. Brain Res 894:311-315.

Robinson TE, Berridge KC (2000) The psychology and neurobiology of addiction: an incentive-sensitization view. Addiction 95:S91-S117.

Robinson TE, Kolb B (1999) Alterations in the morphology of dendrites and dendritic spines in the nucleus accumbens and prefrontal cortex following repeated treatment with amphetamine or cocaine. Eur J Neurosci 11:1598-1604.

Self DW, Barnhart WJ, Lehman DA, Nestler EJ (1996) Opposite modulation of cocaine-seeking behavior by D1- and D2-like dopamine receptor agonists. Science 271:1586-1589.

Sutton MA, Schmidt EF, Choi KH, Schad CA, Whisler K, Simmons D, Karanian DA, Monteggia LM, Neve RL, Self DW (2003) Extinction-induced upregulation in AMPA receptors reduces cocaine-seeking behaviour. Nature 421:70-75.

Tella SR (1994) Differential blockade of chronic versus acute effects of intravenous cocaine by dopamine receptor antagonists. Pharmacol Biochem Behav 48:151-159.

Tsien JZ, Chen DF, Gerber D, Tom C, Mercer EH, Anderson DJ, Mayford M, Kandel ER, Tonegawa S (1996) Subregion- and cell type-restricted gene knockout in mouse brain. Cell 87:1317-1326.

Tzschentke TM (1998) Measuring reward with the conditioned place preference paradigm: a comprehensive review of drug effects, recent progress and new issues. Prog Neurobiol 56:613-672.

White FJ, Kalivas PW (1998) Neuroadaptations involved in amphetamine and cocaine addiction. Drug Alcohol Depend 51:141-153.

Wise RA (2000) Addiction becomes a brain disease. Neuron 26:27-33.

Wolf ME (1998) The role of excitatory amino acids in behavioral sensitization to psychomotor stimulants. Prog Neurobiol 54:679-720.

Xu M, Moratalla R, Gold LH, Hiroi N, Koob GF, Graybiel AM, Tonegawa S (1994a) Dopamine D1 receptor mutant mice are deficient in striatal expression of dynorphin and in dopamine-mediated behavioral responses. Cell 79:729-742.

Xu M, Hu XT, Cooper DC, Moratalla R, Graybiel AM, White FJ, Tonegawa S (1994b) Elimination of cocaine-induced hyperactivity and dopaminemediated neurophysiological effects in dopamine D1 receptor mutant mice. Cell 79:945-955.

Xu M, Guo Y, Vorhees CV, Zhang J (2000) Behavioral responses to cocaine and amphetamine administration in mice lacking the dopamine D1 receptor. Brain Res 852:198-207.

Zhang D, Zhang L, Lou DW, Nakabeppu Y, Zhang J, Xu M (2002a) The dopamine D1 receptor is a critical mediator for cocaine-induced gene expression. J Neurochem 82:1453-1464.

Zhang J, Zhang D, McQuade JS, Behbehani M, Tsien JZ, Xu M (2002b) c-fos regulates neuronal excitability and survival. Nat Genet 30:416-420.

Zhang L, Lou D, Jiao H, Zhang D, Wang X, Xia Y, Zhang J, Xu M (2004) Cocaine-induced intracellular signaling and gene expression are oppositely regulated by the dopamine $D_{1}$ and $D_{3}$ receptors. J Neurosci 24:3344-3354.

Zhang D, Zhang L, Tang Y, Zhang Q, Lou D, Sharp FR, Zhang J, Xu M (2005) Gene expression changes induced by repeated cocaine administration through the dopamine D1 receptors. Neuropsychopharmacology 30:1443-1454. 